\title{
CROSS-BORDER RELATIONS IN RURAL AREAS (BASED ON LOCAL BORDER TRAFFIC)
}

Izabela Zabielska, Department of Economic and Regional Policy, Faculty of Economic Sciences, University of Warmia and Mazury in Olsztyn, 10-719 Olsztyn, Oczapowskiego 4, Poland, izus@uwm.edu.pl (corresponding author)

Joanna Zielińska-Szczepkowska, , Department of Economic and Regional Policy, Faculty of Economic Sciences, University of Warmia and Mazury in Olsztyn, 10-719 Olsztyn, Oczapowskiego 4, Poland, joanna.zielinska@uwm.edu.pl;

Roman Kisiel, , Department of Economic and Regional Policy, Faculty of Economic Sciences, University of Warmia and Mazury in Olsztyn, 10-719 Olsztyn, Oczapowskiego 4, Poland, kisiel@uwm.edu.pl

The paper aims at presenting to answer: can cooperation within local border traffic (LBT) be a platform for cross-border relationships in rural areas? Rural areas located in the border zone were subjected to analysis, limiting the study area to the Polish Warmia-Masuria Province and the Kaliningrad Oblast of the Russian Federation. For the needs of the present task, survey studies were designed and carried out, targeting rural governments of Warmia-Masuria Province (rural areas) covered by the Agreement on LBT on the Polish side, as well as respondents residing in the Kaliningrad Oblast on the Russian side. Individual interviews represented the basic research method in data collection. The interview questionnaire was the research tool applied. As results from the carried out surveys: crossborder relationships on rural areas within LBT expand economic innovation, infiltrate social and cultural influences, overcome negative stereotypes, and reinforce cooperative habits. Furthermore, they support the development of additional cross-border cooperation area.

Keywords: cooperation, cross-border relations, local border traffic, rural cross-border areas

\section{INTRODUCTION}

On the rising tide of transformations in Poland in the early 1990s, local governments became involved in the trend of European cooperation on the international arena. There was a rapid development in the establishment of cross-border relations, which preceded the creation of internal law norms and structures aimed functionally at pursuing international activities ${ }^{1}$. As a result of the development of these relations, partnerships were effectively created, with inhabitants being actively involved in various projects and grants were successfully obtained. In addition, international events were organised, incentives for investors' activities were provided and the arrival of foreign tourists as well as exchanges were organised (Zabielska, Wojarska, 2016). Thanks to such activity and the focus on local community needs, communes made better use of the opportunities offered by modern international relations. This also concerned communes located in rural areas, particularly those situated in the proximity to the border of the state. Due to such a location, the functional connections of border areas with the internal part of the country have become relatively weaker, therefore, regardless of the level of external support, their development is largely determined by relations with neighbouring areas on the other side of the border (Labędzki, 2013).

With the above in mind, the adopted aims of the study were: 1) diagnosis of cross-border relations in rural areas ${ }^{2}$. The rural areas located in Poland's Warmińsko-Mazurskie Voivodeship and in the Kaliningrad Oblast of the Russian Federation, in which the rules of local border traffic (LBT) apply, were subjected to an analysis; 2) identification the causes of entering into cross-border relations and 3) the resulting benefits, as well as the accompanying obstacles.

The study includes the results of a survey carried out by Zabielska and Zielińska-Szczepkowska (2013) as part of a project "Local Border Traffic with the Kaliningrad Oblast - theories and practice" for the Association of Municipalities of the Republic of Poland Euroregion Baltic, as commissioned by the Ministry of Foreign Affairs of the Republic of Poland, Department of Public and Cultural Diplomacy. The study was updated in 2015.

For the purposes of this task, a survey was designed and sent to 59 units of rural communal governments of Warmińsko-Mazurskie Voivodeship, covered by the Agreement on LBT on Polish side, and to 26 rural communes of the Kaliningrad Oblast on Russian side.

\footnotetext{
${ }^{1}$ In the study, the authors adopted the terms "international activity" and "foreign activity" as synonyms.

${ }^{2}$ The analysis presented in the study covers rural areas selected on the basis of the territorial division according to the National Register of the Official Territorial Division of the Country (TERYT), in which rural communes and the rural part of rural-and-urban communes are regarded as rural areas. For the purposes of this analysis, rural communes were adopted as rural areas [file:///C:/Users/admin/Downloads/rl_obszary_wiejskie_w_polsce_2010.pdf].
}

Copyright (C) 2017 The Authors. Published by Aleksandras Stulginskis University. This is an open-access article distributed under the terms of the Creative Commons Attribution License (CC-BY 4.0), which permits unrestricted use, distribution, and reproduction in any medium, provided the original author and source are credited. 
The basic research method in the collection of data involved individual interviews. An in-depth interview was adopted as the research technique. The research tool developed for this purpose was an interview questionnaire.

\section{CROSS-BORDER RELATIONS AS AN ELEMENT OF CONNECTIONS IN INTERNATIONAL RELATIONS}

The activity of local self-governments at an international level has become an important subject of research (inter alia: Baldersheim and Ståhlberg, 1999; Aldecoa and Keating, 1999; Paasi, 1999; Perkmann, 1999; Scott and Storper, 2003). This research primarily focuses on the ways to develop this type of involvement and its effect on socio-economic development of (local and regional) governments and on their integration (Szmigiel, 2009). On this basis, the concept of the scale of a region with regard to its relations (including cross-border relations) (Kaplan, 1998; Sheppard, 2002; Herod, 2003; Howitt, 2003; Paasi, 2004) and, therefore, their intensity and range, has been developing.

It should be emphasised here that the cross-border activity of local self-governments is a consequence of dynamic changes in international relations (Zabielska, Wojarska, 2016). This is primarily reflected in an increase in the intensity of connections, and in the range and the number of participants in international relations. This is also the expression of changes taking place in activities of regional and local authorities, particularly since the early 1990s, when contacts with foreign countries were decentralised. At that time, regulations were introduced which assigned to voivodeships, counties and municipalities/communes the competence to establish cooperation with their foreign counterparts. Local government relations with foreign countries have become an essential management element (Swianiewicz, 2005).

Pursuant to Article 172 of the Constitution of the Republic of Poland (1997) and relevant acts, municipalities (and communes) as well as other levels of local self-government in Poland have the power to establish cross-border relations expressed in cooperation. These regulations are also in line with international law ratified by Poland (compare e.g. Goldsmith, Klausen, 1997). On this basis, they have developed a traditional pattern of establishing their relations, based on local border cooperation, and an institutional one, which involves signing bilateral agreements (compare Newman, Paasi, 1998). However, despite an increase in communes' activity on the international scene in Europe, the traditional model is still commonly applied and frequently adopted as a measure of the involvement concerned (compare e.g. The legislative and institutional framework..., 2003) (as cited in: Szmigiel, 2009).

Studies into contacts (including cross-border ones) of Polish self-governments (also communal ones) with foreign countries indicate that the most common causes of their establishment are as follows: (Fuksiewicz et al., 2012):

- providing inhabitants with opportunities for international exchange (78\% of the obtained responses);

- the promotion of a local government unit on the international scene (75\%) and prestige (24\%);

- the transfer of good practices from foreign government units to the local ground (70\%);

- a possibility for applying for funds from Polish, European, and international programmes (57\%);

- the development of officials' knowledge and competence as a result of the constant exchange (51\%);

- striving for gaining influence on decisions concerning local government, taken by the EU institutions (11\%);

- encouragement from Polish administration (including central administration) (6\%).

On this basis, international and cross-border relations develop ${ }^{3}$ and cooperation becomes their catalyst. In this context, the relations of communal governments in these considerations are interpreted as an ability to maintain close and lasting relationships, and openness to foreign countries (Pawłowska, 2008) and they can be considered equivalent to a network of connections between particular elements, i.e. entities (Skrzypek, 2005). This is none other than the capital of external ties, interests and relationships (Biernat, 2006; Edwisson and Malone, 2001) and, consequently, highly developed abilities to cooperate with people, entities and institutions being culturally similar to each other.

This term has been used ${ }^{4}$ consciously, yet the authors are aware that the main subject of research is the connections and influence which cannot be completely referred to as relations. This follows from the fact that the analyses included in the study relate to the area of international relations and this is the cross-border relations that are the subject of inquiries. Therefore, such presentation of relations is intended to show that the study deals with issues which are similar, but not identical, to those analysed in the field of international relations (Szmigiel, 2009).

In these considerations, the forms, expressions and types of relations are systematised using the metaphor of a "ladder whose successive rungs" describe the closer and more intensive scope of connections occurring within a commune ${ }^{5}$. Therefore, it was assumed that cross-border relations may exist in the form of:

- the mutual recognition and exchange of information;

- a joint analysis of problem issues of interest to stakeholders (through the activity of mixed working groups);

- working out common positions in negotiations, the presentation of common opinions on possible solutions to specified problems;

- the implementation of joint projects;

- the institutionalisation of the joint performance of tasks in the field of cooperation for development.

\footnotetext{
${ }^{3}$ The literature puts a stress on distinguishing between cooperation and relations. As reported by Szmigiel (2009, p. 11), the concept of relations is broader than that of cooperation. This is because in the international context, the definition of relations includes not only cooperation but also conflict and competition.

${ }^{4}$ The term relation (Latin: relatio) denotes a relationship between objects, concepts, values, etc. https://sjp.pwn.pl/sjp/relacja;2573836.html accessed on: 10 November 2017

${ }^{5}$ This part of the chapter was drawn up based on: Zabielska (2010).
} 
Based on the literature review (Martinez, 1994; Miszczuk, 2008), all cross-border relations in which local selfgovernment units can participate have been divided into four categories, namely:

1) hostility - as an effect of sudden political events. It intensifies when these events result in territorial decisions that are unjust to a local community

2) coexistence - exchange of information which takes place on different planes and between various entities. Such relations serve to get to know partners, and to organise public administration and customs, tax and other regulations related to economic activity. They are also aimed at overcoming historical resentments and stereotypes of thinking and behaviour;

3) cooperation - increases the intensity of contacts between neighbouring regions on all cooperation planes (public security, education, scientific research, culture and sports). Trade (including non-registered trade) develops as well. This stage initiates the process of forming a cross-border region;

4) interdependence - denotes tightening the ties through the flow of employees, technological connections and undertaking joint, partner ventures.

At the stage of cooperation or interdependence, institutionalisation of a cross-border region may occur through the establishment of a Euroregion.

Salmonowicz (1999) emphasises that practically all areas of economic life are penetrated by integration processes creating a network of relations crossing political and institutional boundaries. This particularly concerns the development of a variety of concepts of cross-border regional cooperation, the establishment of cross-border communities (regional and subregional) or the formation of trans-national regions.

This is of exceptional importance in the context of the development of rural areas.

\section{RURAL AREAS IN THE WARMIŃSKO-MAZURSKIE VOIVODESHIP - DIAGNOSIS OF THE STATE}

Rural areas in Poland ${ }^{7}$ are of significance. The countryside is a place of residence for half of Poland's population; it is a source of income for every third Pole and every fourth inhabitant's place of work is situated there (Lizińska, 2005, pp. 245-252). However, in recent years, its image has been changing. The countryside, until recently associated primarily with the production of food and agricultural raw materials, currently serves numerous new functions, inter alia related to the consumption and services, and not only to agricultural production (Kłodziński, 2012, as cited in: Babuchowska, Marks-Bielska, 2013). This is inter alia due to the EU policy and the so-called second pillar of the common agricultural policy. The above-mentioned influence is not, however, uniform. It results in distinguishing more developed rural areas located in proximity to the centre and close to markets. Remote, i.e. peripheral, rural areas are also formed, which are characterised by infrastructural shortages and strong dependence on agriculture (for example, Warmińsko-Mazurskie Voivodeship) (Stathopoulou et al., 2010, as cited in: Babuchowska, Marks-Bielska, 2013).

It should be stressed that Poland's accession to the EU additionally provided new opportunities for development. Instruments have emerged which enable inter alia the establishment and strengthening of cross-border relations in rural areas, co-financed from the EU budget (primarily legal and administrative opportunities for pursuing cross-border cooperation). On this basis, international activation of rural areas of Warmińsko-Mazurskie Voivodeship has become possible as well. Their development (modernisation of agricultural production) and the creation of conditions for the formation of non-agricultural sources of income for the rural population have developed a platform for the foreign activities of the region (Zabielska, Wojarska, 2016) ${ }^{8}$. Such activation, which is a continuation of the assumptions of Poland's foreign policy, is regarded as a significant element of the strategy for shaping the socio-economic development of the voivodeship. Thanks to it, the developed cross-border relations, in accordance with Priorities of foreign cooperation of WarminskoMazurskie Voivodeship (2014), offer tangible benefits of a economic and political, social and cultural nature. In addition, in the longer term, they enrich the integration connections, and serve the function of a "bridge" with regions of non-EU countries (a link for Warmińsko-Mazurskie Voivodeship and the Kaliningrad Oblast of the Russian Federation).

This is important from the perspective of Warmińsko-Mazurskie Voivodeship, which is characterised by a certain difference in relation to other regions of Poland (strong historical determinants). The development processes taking place from 1989 under the conditions of market economy were not able to reduce the distance in relation to other voivodeships. In addition, the (above-mentioned) rural nature of the area, low population density and decapitalised technical, economic and social infrastructure have not contributed to this to a large extent. Moreover, the border of the state (with the Russian Federation) established in this area, and the remoteness from the main centres of growth, both in the country and on the other side of the border, have become an obstacle.

Further considerations are dedicated to the issue of the specificity of the Polish-Russian border.

\section{THE NATURE OF LOCAL BORDER TRAFFIC ON THE POLISH-RUSSIAN BORDER}

The process of development of Polish-Russian cross-border relations only began after 1990 (following the system transformation in Poland and the dissolution of the Soviet Union). This was due to the changing legal environment,

\footnotetext{
${ }^{6}$ Such an example is the Polish-Russian border.

${ }^{7}$ Rural areas in Poland occupy $93.2 \%$ of the national area, and are inhabited by just over 15 million people, i.e. $39 \%$ of the country's population, including approx. 9.6 million people of working age.

${ }^{8}$ It was important, for example, because of the features of Warmińsko-Mazurskie Voivodeship (inter alia, the area structure, the level and sources of income, the quality of soils and the directions and scale of the marketability of production) (Lizińska, 2005).
} 
liberalisation of regulations and the opening of the border, because until then, the border between Poland and the Kaliningrad Oblast of the Russian Federation, formed after 1945, used to be among the most heavily guarded borders in Europe at that time. Its uniqueness was emphasised by its artificial and authoritarian course, which did not take into account local natural, social, administrative and economic conditions. At that time, the Kaliningrad Oblast of the Russian Federation became a place of settlement for a selected group of people connected economically or socially with the dominant military complex (Kostyaschov, 2000).

An economic crisis in Russia in 1998 and legal changes associated with Poland's accession to the EU and the Schengen Area (the so-called Schengen Borders Code), resulted in the deterioration of mutual relations [Regulation (EC) No $562 / 2006]^{9}$. Further signs of revival could be seen again in 2010. A real opportunity for breaking the stagnation was offered by the agreement on local border traffic (hereinafter referred to as LBT) in December 2011. ${ }^{10}$ The massive increase in the number of people crossing the border during that period (more than 6 million people per annum until the year 2016) raised hopes of a new stage in the development of connections ${ }^{11}$, all the more so because the European Communities began to take significant efforts in order to ensure that borders with the neighbouring countries would not be barriers to trade, social and cultural exchange or regional cooperation (Regulation (EC) No 1931/2006). Therefore, with the approval of the European Commission, the Member States had an opportunity to sign (bilateral) agreements on LBT with their non-EU neighbours. Under such an Act, inhabitants of the border regions of the contracting parties (up to $30 \mathrm{~km}$, and in particular cases, up to $50 \mathrm{~km}$ deep into the territory of each of the countries) could regularly cross the common border to stay within the border zone of the second country for social, cultural, or family-related reasons and for justified economic reasons ${ }^{12}$, for a period not exceeding the set time limits (Regulation (EC) 1931/2006).

In the area under study, the facilitations in crossing the Polish-Russian border by inhabitants of the border zone were applicable to seven seaside counties of Pomorskie Voivodeship ${ }^{13}$ and to 13 counties of Warmińsko-Mazurskie Voivodeship ${ }^{14}$ as well as the area of the Kaliningrad Oblast of the Russian Federation ${ }^{15}$ and the duration of a one-time stay was no longer than 30 days (Fig. 1).

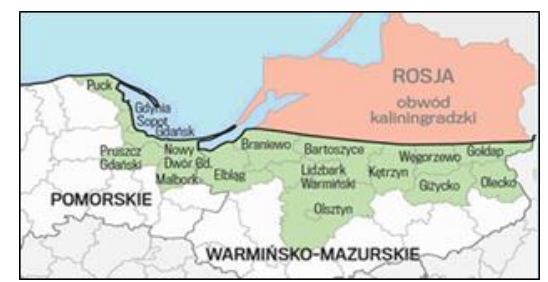

Figure 1. The local border traffic area

\section{LOCAL BORDER TRAFFIC AS A PLATFORM FOR THE DEVELOPMENT OF RELATIONS IN RURAL AREAS IN COMMUNAL GOVERNMENT OPINIONS}

In the context of the performance of the task (the main aim of the analyses), an important role was served by a survey of opinions of the representatives of local authorities, which was to provide an answer to the question as to whether local border traffic can become a platform for the development of cross-border relations in rural areas in WarmińskoMazurskie Voivodeship?

In the survey a total of 59 communes from rural areas of Warmińsko-Mazurskie Voivodeship participated, and 26 rural communes from the Kaliningrad Oblast of the Russian Federation ${ }^{16}$ located within the LBT area ${ }^{17}$.

Estimates show that in approx. $70 \%$ of communes, thanks to the involvement on the international scene, cooperation is implemented as part of the local border traffic (LBT) and additional areas have developed there. This mainly concerns contacts between partners and the exchange of professional experience (35\% of the obtained responses) and cross-border trips, particularly as part of study visits (approx. 30\%). Another significant form is the participation in

\footnotetext{
${ }^{9} \mathrm{OJ}$ L 105 of 13.04 .2006 , p. 1.

${ }^{10}$ The Community also established specific criteria and conditions for granting permits for crossing the border as part of the LBT to inhabitants of the border zone. They are in accordance with the conditions for entry applicable to the border zone inhabitants crossing the external land border.

${ }^{11}$ In connection with the NATO summit and the World Youth Days, Poland decided to suspend, as from 4 July 2016 , the provisions of international agreements on LBT in the part concerning the entry and stay in the territory of the Republic of Poland of the inhabitants of the border zone of Ukraine and the Russian Federation. Local border traffic with Ukraine was restored after the World Youth Days, while the traffic with the Kaliningrad Oblast has never been restored.

${ }^{12}$ Ministry of Foreign Affairs, Local traffic border, www.msz.gov.pl/pl/informacje_konsularne/maly_ruch_graniczny

${ }^{13}$ The counties: of Puck, the city of Gdynia, the city of Sopot, the city of Gdańsk, of Gdańsk, Nowy Dwór and of Malbork.

${ }^{14}$ The counties: city of Elbląg, of Elbląg, of Braniewo, of Lidzbark, of Bartoszyce, the city of Olsztyn, of Olsztyn, of Kętrzyn, of Mrągowo, of Węgorzewo, of Giżycko, of Gołdap and of Olecko.

${ }^{15} \mathrm{~A}$ non-standard extension of the border zone $(30 \mathrm{~km})$ adopted by the European Commission resulted from the location of the city of Kaliningrad at a greater distance from the border, and the possible failure to apply the LBT rules to this city.

${ }^{16}$ The Kaliningrad Oblast is one of 89 subjects of the Russian Federation. Its administrative division comprises three levels: the first level is the entire oblast, the second level is the part of cities with "oblast" significance and one urban settlement, and the third level is comprised of 66 communes, including 19 urban communes and 47 rural communes.

${ }^{17}$ The Kaliningrad Oblast of the Russian Federation only districts: Bagrationovsky, Pavdinsky, Ozersky, Niestersky, Gusievsky, Chernyakhovsky, Gvardeysky, Gurevsky.
} 
international cooperation networks. In addition, in rural areas of Warmińsko-Mazurskie Voivodeship, cooperation with municipal units of the Kaliningrad Oblast of the Russian Federation was pursued ${ }^{18}$ :

- based on bilateral or multilateral agreements;

- within Euroregions: the Baltic, the Neman, the Lyna-Lava;

- in an informal form based on personal contacts.

Therefore, communes are of the opinion (70\% of indications) that "appropriate" cross-border relations offer an opportunity for strengthening of ties, and consequently for the development of cooperation and faster development of a commune. This is particularly noticeable during the period of the existing agreement on local border traffic. At that time, communes noted a change in the intensity of contacts between the cooperating partner regions. In addition, in the opinion of local government, the state of mutual relations was assessed as rather good. A majority (as many as approx. 30\%) indicate a "very good" or "good" level. However, 50\% respondents find it difficult to provide a definitive answer, and their uncertainty is due to the short period of the functioning of the facilitations resulting from local border traffic.

The further part of the analysis focused on the features of a commune which enable the development of mutual relations thanks to facilitations resulting from the Local Border Traffic. The most frequently mentioned parameter was the proximity to the border (over $60 \%$ of responses). The following have become the subsequent significant areas: convenient communication system, inter alia major routes, the local community's involvement in cooperation and entrepreneurs' involvement in maintaining various contacts with foreign partners (approx. 30-35\% of the total of indications each). The attractive and unpolluted natural environment with a significant percentage of protected areas (25\%), knowledge of the situation on the other side of the border (13\%), or the presence of expansive enterprises (5\%) were indicated slightly less frequently.

Respondents also assessed the benefits of mutual cross-border relations associated with the validity of the agreement on LBT with the Kaliningrad Oblast of the Russian Federation. In the opinion of the local government representatives, the greatest benefits were seen in the revival of tourism traffic (30\% of indications). Moreover, there was an increase in trade $(20 \%)$ and capital flow (15\%). It was also found that the strengthening of relations thanks to the implementation of the agreement on LBT resulted in the revival of cultural exchange (approx. 15\%). There was no significant increase in investments in a commune and no improvement in mutual relations between local communities.

Another aim of the study was to determine the effect of the agreement on LBT with the Kaliningrad Oblast of the Russian Federation in the context of socio-economic activation within a commune. In $16 \%$ of cases, it has not become an inspiration for socio-economic revival. In turn, $27 \%$ of all indications confirmed a much better influence, while $57 \%$ stated that the situation was the same. The respondents made this influence subject to, respectively:

- the overall financial improvement in communes' budgets (23\% of responses);

- the unification of legislations on both side of the border (19\% of responses);

- an increase in activity of industrial and commercial institutions (16\% of responses);

- the recognition of cross-border cooperation by the community as an important element of activity and an increase in the involvement of the public in this process and thus an improvement in mutual relations (14\% of responses);

- an increase in activity of business entities (14\% of responses);

- greater involvement in the improvement in mutual relations of the State administration offices (14\% of responses).

Therefore, what else could improve the Polish-Russian cross-border relations? These are the following:

1. legal and administration facilities e.g. in the field of customs and tax regulations (24\% of responses);

2. increased access to EU funds for financing cross-border cooperation (18\%);

3. greater involvement in cooperation of enterprises (business entities) (18\%);

4. transport improvements and a better quality of technical infrastructure factors $(14 \%)$;

5. the development of cross-border facilities (8\%);

6. increased opportunities for the use of aid measures from national funds (7\%);

7. the activity of regional organisations and institutions, contributing to the development of mutual relations (7\%);

8. greater involvement in the improvement in public relations $(5 \%)$.

In addition, the level of current cross-border relations of communes does not correspond to their potential. This results from many accompanying obstacles occurring on both Polish and Russian side. An attempt was made to systematise the problems that prevent the improvement.

Considering the scores given to particular barriers, it was observed that the following were characterised by the highest degree of nuisance:

- on Polish side - the lack of own funds earmarked for cooperation (over $40 \%$ of indications), difficulties in finding crossborder partners (16\%), and legal and administrative barriers (13\%);

- on Russian side - legal and administrative barriers (26\%); the lack of own funds earmarked for cooperation, and the limited access to information on a partner (12\% each).

Some barriers are of social and cultural nature, because the inter-personal factor is often decisive in cross-border relations (psychological barriers; the limited access to information on a partner; lack of knowledge of a foreign language). Therefore, a number of measures should be taken to eliminate barriers and obstacles on the one hand, and on the other,

\footnotetext{
${ }^{18}$ Moreover, Kętrzyn, Barciany, Korsze, Srokowo, Mrągowo, Kętrzyn and Reszel have been pursuing cooperation within the framework of the "Barcja" Association of Municipalities „Barcja” (since 1991), the aim of which was the promotion of the idea of the establishment of the border crossing Michałkowo-Zheleznodhorozhnyi. More information can be found in: www.barcja.org.pl. Cooperation is also pursued by five communes of the voivodeship as part of the Municipal Association of the Lagoon Area Communities in the field of environmental protection and activation (in economic and tourism terms) of the area of the Vistula Lagoon and Vistula Spit.
} 
actions will be taken to improve mutual cross-border relations. According to the majority of respondents, this should be addressed by local government authorities (35\% of obtained responses) with the support of central authorities and business entities.

\section{CONCLUSIONS}

The process of development of Polish-Russian cross-border relations only began after 1990, because until then, the border between Poland and the Kaliningrad Oblast of the Russian Federation used to be among the most guarded borders and was a significant barrier. The changes taking place after 1989, associated with the system transformation in Poland and the dissolution of the Soviet Union, offered an opportunity for the re-establishment of mutual relations based on institutional, economic and social cooperation. In addition, the agreement on local border traffic (hereinafter referred to as LBT), signed in December 2011, strengthened the initiated process. On this basis, cross-border activity of rural communal governments has been established and reflected in: 1) the mutual recognition and exchange of information; 2) an analysis and working out common positions concerning cross-border problem issues; 3 ) the implementation of joint cross-border projects.

The aim of consideration was to examine (a diagnosis) the occurring cross-border relations in rural areas (based on the example of Warmińsko-Mazurskie Voivodeship and of the Kaliningrad Oblast of the Russian Federation), in which the rules of local border traffic apply. The established and maintained relations were mainly pursued on the basis of bilateral agreements or within Euroregions and even informally on the basis of personal contacts. Such activity took the form of official visits of the representatives of local authorities and officials, or directed cooperation. Moreover, joint projects were implemented and actions were taken on the basis of a permanent partnership.

In addition, the conducted study demonstrated that local authorities were aware of the significance of the state of cross-border relations in the development of their units. This is contributed to by, in the following order: the proximity to the border, convenient communication system, local community and entrepreneurial involvement in maintaining various forms of cooperation pursued in that area.

In conclusion, the following general questions arise: Are there any benefits of mutual cross-border relations associated with the validity of the agreement on LBT? What is the agreement's effect on these relations? It appears that the added value is the increased access to EU funds for financing cross-border cooperation, the revival of tourism traffic and an increase in trade and capital flow.

However, the authors propose actions that will improve mutual cross-border relations:

1) a wider legal and administration facilities e.g. in the field of customs and tax regulations; 2) to increase access to EU funds for financing cross-border cooperation; 3) increased opportunities for the use of aid measures from national funds; 4) to boost involvement in cooperation of business entities and the activity of regional organisations and institutions; 5) the development of cross-border facilities; 6) the recognition of cross-border relations by the community as an important element of activity and an increase in the involvement of the public in this process.

Consequently, it can be expected that the barriers to development resulting from both the location of the areas concerned and the mindset of the population of this area will be removed...

\section{REFERENCES}

1. Aldecoa, F., Keating, M. 199. Paradiplomacy in Action. The Foreign Relations of Subnational Governments. London, Portland: Frank Cass.

2. Babuchowska, K., Marks-Bielska, R. 2013. The growth of rural entrepreneurship in the context of the implementation of the Rural Development Programme in 2007-2013. Rural Development 2013: Innovations and Sustainbility. Aleksandras Stulginskis University, Akademija, Kaunas district, Lithuania, Proceedings of the Fifth International Scientific Conference, 28-29 November, 2013), pp. 493-498.

3. Baldersheim, H., Stahlberg, K. (red.) 1999. Nordic Region Building in a European Perspective, Aldershot, Ashgate.

4. Biernat, J. 2006. Value of public relations - relations' capital. in: Public Relations in theory and practice, ed. D. Tworzydło, T Soliński, Ed. WSIiZ, Rzeszów.

5. Buczkowski, Ł. Żukowski, L. Forms of international cooperation of local government bodies. (Accessed on 10/11/2017).

6. Constitution of the Republic of Poland. 1997. http://www.sejm.gov.pl/prawo/konst/polski/kon1.htm. (Aaccessed on 10/11/2017).

7. Edwinsson, L., Malone, M. 2001. Intellectual capital, PWN Warsaw.

8. Fuksiewicz, A., Łada, A., Wenerski, Ł. 2012. Foreign cooperation of Polish local governments. Study results Public Affairs Institute Studies. Expert reports. Recommendations. Warsaw.

9. Goldsmith, M., Klausen, K. 1997. European integration and local government, Cheltenham: Edward Elgar Publishing.

10. Herod, A. 2003. Scale: the global and local. In Holloway, S.L., Rice, S.P. and Valentine, G., editors, Key concepts in geography, London: Sage, pp. 229-247.

11. Howwit, R. 2003:Scale. InAgnew,J., Mitchell, K., Toal, G. A companion to political geography, Oxford: Blackwell, pp. $138-157$.

12. International cooperation of local governments. 2017. Expert reports and Opinions. OE-261. Senate Chancellery Office of analyses, documentation and correspondence. Warsaw. 
13. Kaplan, D.H. 1998: Territorial identities and geographical scale. In Herb, G.H. and Kaplan, D.H., editors, Nested identities: nationalism, territory and scale, Lanham: Rowman and Littlefield, pp. 31-49.

14. Kłodziński, M. 2012. Bariery wielofunkcyjnego rozwoju obszarów wiejskich. Wieś i Rolnictwo, No. 2(155), pp. 40-56. [In Polish]

15. Kostjaszow, J.W. 2000. The displaced tell their story. The first years of the Kaliningrad Oblast in memories and documents. Hojszyk W. (tł.). OBN im. W. Kętrzyńskiego, Olsztyn. [In Polish]

16. Łabędzki, H. 2010. Transformations along the borderland rural areas in south-western Poland. Natural University, Wrocław

17. Lizińska ,W. 2005. Entrepreneurship development in rural areas of the warmińsko-mazurskie voivodeship. (in:) Kopycińska D. (ed.) Competitiveness of the labour market and its entities. Library of Economics \& Competition Policy, University of Szczecin, pp. 245-252

18. Martinez, O. 1994. The dynamics of border interaction: new approaches to border analysis. W: SCHOFIELD C.H. (ED.): Global Boundaries, World Boundaries. Vol. I, Routledge, London, pp. 1-15

19. Miszczuk, A. 2008. State border as an international condition for regional development. In: H. Ponikowski, Jóźwik B. International conditions for regional development. Higher School of Entrepreneurship and Administration, Lublin, pp. 71-82

20. Newman, D., Paasi, A. 1998. Fences and neighbours in the postmodern world: boundary narratives in political geography. Progress in human geography, Vol. 22, No. 2, pp. 186-207.

21. Paasi, A. 1999. Boundaries as social practice and discourse: the Finnish-Russian Border. Regional Studies, Vol. 33, No. 7, pp. 669-680.

22. Paasi, A. 2004. Place and Region: Looking Through the Prism of Scale. Progress in Human Geography, Vol. 28, No. 4, pp.536-546.

23. Pawłowska, K. 2008, http://wiadomosci.nf.pl/News/13559/Kapital-relacyjny-przynosi-pracownikom-wielkie-zyski/,,(Accesed on 10/11/2017). [In Polish]

24. Perkmann, M. 1999. Building Governance In stitutions across European Borders, Regional Studies, t. 33, $n r$ 7, s. $657-667$.

25. Priorities of foreign cooperation of the warmińsko-mazurskie voivodeship.2014. Assembly of the warmińsko-mazurskie voivodeship. Olsztyn. [In Polish]

26. Salmonowicz, H. 1999. Determinants of cooperation and economic integration of borderland regions. Series: Dissertations and studies. Ed. Naukowe Uniwersytetu Szczecińskiego, Szczecin.

27. Scott, A.J., Storper, M. 2003. Regions, Globalization, Development. Regional Studies, Vol. 37, No. 6/7, pp. $579-593$.

28. Sheppard, E. 2002. The spaces and times of globalization: place, scale, networks, and positionality. Economic Geography, Vol. 78, pp. 307-330. https://doi.org/10.2307/4140812

29. Skrzypek, E. 2005. Intellectual capital as an opportunity for improvement of management quality in globalisation conditions. Ed. UMCS Lublin.

30. Stathopoulou, S., Psaltopoulos, D., Skuras, D. 2004. Rural entrepreneurship in Europe. A research framework and agenda. International Journal of Entrepreneurial Behaviour \& Research, $\quad$ Vol. $10 \quad$ No. $\quad 6, \quad$ pp. $404-425$. https://doi.org/10.1108/13552550410564725

31. Swianiewicz, P., 2005. International contracts of local governments. Territorial Government, No.10, Ed. KiK, Warsaw pp. 7-27.

32. Szmigiel K. 2009. Acting at a regional level. Why and with whom? International relations of provincial governments. GEOPROFIT, Warsaw.

33. Regulation (EC) No 562/2006 Of the European Parliament and of The Council Of 15 March 2006. Establishing a Community Code On The Rules Governing The Movement Of Persons Across Borders (Schengen Borders Code). OJ L 105 of 13.04.2006.

34. Regulation (EC) No 1931/2006 Of The European Parliament And Of The Council of 20 December 2006 laying down rules on local border traffic at the external land borders of the Member States and amending the provisions of the Schengen Convention. Journal of Laws of 30.12.2006, p. 1 (OJ L 405 z 30.12.2006).

35. The legislative and institutional framework for regional partnership. Report (2003). Dijon: Working Group Regional Partnership Committee Institutional Affairs of the Assembly of European Regions.

36. Trzcielinska-Polus, A. 2015. Local governmental dimension of foreign policy of regions (based on the example of Śląsk Opolski). Borderland. Polish Borderlands Studies, Vol. 3, No. 2, pp. 117-133.

37. Zabielska, I. 2010. The importance of Russian - Polish neighborhood in the economic development of Warmia and Mazury: Doctoral dissertation (typescript). Olsztyn.

38. Zabielska I., Wojarska M. 2016. International activity of local governments based on an example of local government bodies of the warmińsko-mazurskie and podlaskie voivodeships. In: Przygodzka R., Chmielak A. Cross-sectoral cooperation - nature, examples, benefits. PTE, Białystok, pp. 281-295.

39. Zabielska, I.; Zielinska-Szczepkowska, J. 2013. "Costs - Benefits" entry into force of the agreement border traffic and the Kaliningrad oblast RF - elaboration based on study results. [Available at: http://eurobalt.org.pl/40-strona,badania.html

40. file:///C:/Users/admin/Downloads/rl_obszary__wiejskie_w_polsce_2010.pdf (Accessed on: 10/11/2017)

41. www.barcja.org.pl (Accessed on: 10/11/2017)

42. https://sjp.pwn.pl/sjp/relacja;2573836.html (Accessed on: 10/11/2017).

43. www.msz.gov.pl/pl/informacje_konsularne/maly_ruch_graniczny (Accessed on: 10/11/2017). [In Polish] 